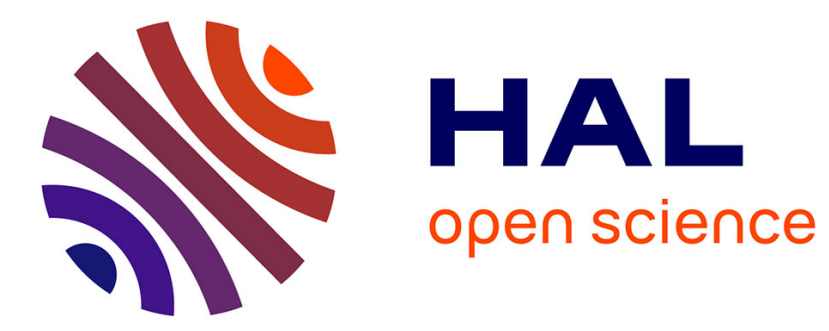

\title{
Trade and Institutions: Explaining Urban Giants
}

Fabien Candau, Tchapo Gbandi

\section{To cite this version:}

Fabien Candau, Tchapo Gbandi. Trade and Institutions: Explaining Urban Giants. Journal of Institutional Economics, 2019, 15 (6), pp.1017-1035. 10.1017/S1744137419000328 . hal-02416125

\section{HAL Id: hal-02416125 \\ https: / hal-univ-pau.archives-ouvertes.fr/hal-02416125}

Submitted on 17 Dec 2019

HAL is a multi-disciplinary open access archive for the deposit and dissemination of scientific research documents, whether they are published or not. The documents may come from teaching and research institutions in France or abroad, or from public or private research centers.
L'archive ouverte pluridisciplinaire HAL, est destinée au dépôt et à la diffusion de documents scientifiques de niveau recherche, publiés ou non, émanant des établissements d'enseignement et de recherche français ou étrangers, des laboratoires publics ou privés. 


\title{
Trade and Institutions: Explaining Urban Giants
}

\author{
Fabien Candau*and Tchapo Gbandi ${ }^{\ddagger}$
}

May 30, 2019

Forthcoming in Journal of Institutional Economics.

\begin{abstract}
By analyzing the population growth at the top of the urban hierarchy, we test two hypothesis explaining the rise of mega-cities: trade and political institutions. We find that democratic institutions are the main factor behind the concentration of a nation's urban population in the main city. Contrary to the literature, we find that extractive institutions reduce the size of the biggest city.

JEL: F12, O10, R12, P16. Keywords: Democracy, Urban Primacy, Market Access.
\end{abstract}

\section{Introduction}

From the 18th century to date, urbanization has been an important process all around the world and despite the apparent chaotic evolution of cities, many regularities in the spatial economy have been explained by considering economic factors only. This is typically the case of the Zipf's law ${ }_{1}^{1}$ which is usually explained by random productivity process of local economies and migrations between cities (Eeckhout, 2004). To describe deviation from this

* Center for the Analysis of Trade and Economic Transition, Université de Pau et des Pays de l'Adour, Pau, France. fabien.candau@univ-pau.fr

${ }^{\dagger}$ Center for the Analysis of Trade and Economic Transition, Université de Pau et des Pays de l'Adour, Pau, France. gbanditchapo88@gmail.com

${ }^{\ddagger}$ Acknowledgement: We thank Elisa Dienesch, Geoffroy Guepie, Charles Régnacq, Julie Schlick and many conference and seminar participants, especially Antonio Accetturo for its discussion at the 13th Meeting of the Urban Economics Association (New York City, Columbia U.), for their valuable comments.

${ }^{1}$ The Zipf's law states that the size of the largest cities is inversely proportional to their rank in the size distribution of cities. 
law, it seems however necessary to introduce additional factors. For instance how to explain that Mexico city is much bigger than just twice the size of the second largest city in this country; is it the historical centralization of the political powers in that city or its unique market access to the world ? This is the question addressed in this paper that aims to better understand what explains urban primacy.2 We find that democratic institutions are the main factor behind the concentration of a nation's urban population in the main city; trade liberalization and good market access are not significant.

Our research area is related to a vast literature. The agglomeration of the population in the nation's largest city has been explained by many mechanisms, often related to political institutions (Lipton, 1977; Bates, 1981). In countries where urbanization goes hand in hand with industrialization, capital accumulation in the industrial sector can lead rent seeker' governments to favor fiscal centralization and as a consequence, the agglomeration of the population in the largest city (Davis and Henderson, 2003). In states with extensive regulation, where licenses and permits are necessary for a myriad of activities (to start a business, to hire or to fire workers, to register property and so on), the decision to be near the administrative center is beneficial since it increases the probability of getting these authorizations. Such a probability can be a powerful determinant of location choice for multinational firms which in turn attracts domestic firms and migrants. Furthermore, since bribes, red tape or more generally corruption enable the obtaining of these rights, the centralization of power in the largest city is a "cash machine" for governments. Urban favoritism for the largest city may be a strategy to monopolize (or to polarize) the rent extracted by limiting the competition of bureaucrats and politicians located in other regions. Fiscal centralization not only pulls activities into the urban giants, it also pushes activities outside secondary cities. Indeed, when local governments have little power, this centralization limits the urban planning de facto and also leads to a kind of resistance against urbanization $\left.{ }^{3}\right]^{4}$ Without the ability to integrate new migrants into the formal sector, there is a political fear of agglomerating people. The incidence of crime or revolt is higher in cities, and this may represent an incentive

\footnotetext{
${ }^{2}$ Our main question concerns the urban concentration in the biggest city because such a phenomenon is less understood than other forms of urban change such as urbanization, density or urban growth. Furthermore as it has been pointed out by Crenshaw and Anthony (2014), primate cities are (more than other cities) global political theaters and consequently the identification of the causal impact of globalization and institutions in these cities seems to be the most urgent/logical investigation. Obviously, additional researches on the impact of these variables on different aspects of the spatial economy, using different measures of urban concentration (see Anthony, 2014), would bring interesting additional results.

${ }^{3}$ For instance, Collier and Venables (2013) reports that in Liberia, governments have adopted a deliberate policy of reducing infrastructure investment in order to induce a return of urban residents to the countryside. Feler and Henderson (2011) also document exclusionary policies in the development of Brazilian cities, in particular during the period of dictatorship, where localities withheld public services to deter in-migration.

${ }^{4}$ In contrast, the Chinese fiscal decentralization, started in the 1980s, has been a success into spreading growth by fostering competition between local authorities (Bai, Hsieh and Song, 2019).
} 
for weak local governments to discourage urbanization while on the contrary, strong central government can favor its urban giant.$^{5}$ Ades and Glaeser (1995) support this thesis and find that dictatorial governments have urban giants that are 50 percent larger than democratic governments. ${ }^{6}$ This result however, raises many questions, the most important being: which kind of institutions are the most prone to urban bias? $?^{7}$ Here we challenge the conclusion of Ades and Glaeser (1995) by working on countries colonized by European powers during the past 500 years. We focus on these countries because colonization has deeply modified economies and institutions in these countries, and while many consequences of this colonization has been analyzed in depth, the analysis in terms of urban economics is lagging behind.

As illustrated by Figure (1), former European colonies that were relatively densely populated in the 1500s now have smaller central cities ${ }^{8}$ By considering, along with Acemoglu, Johnson and Robinson (2002), hereafter AJR, that density in 1500 was an indicator of prosperity fostering predatory behaviors and an indicator of the difficulty of settling, leading colonizers to set up extractive institutions, we come to the logical conclusion that these institutions have reduced concentration in the central metropolis.
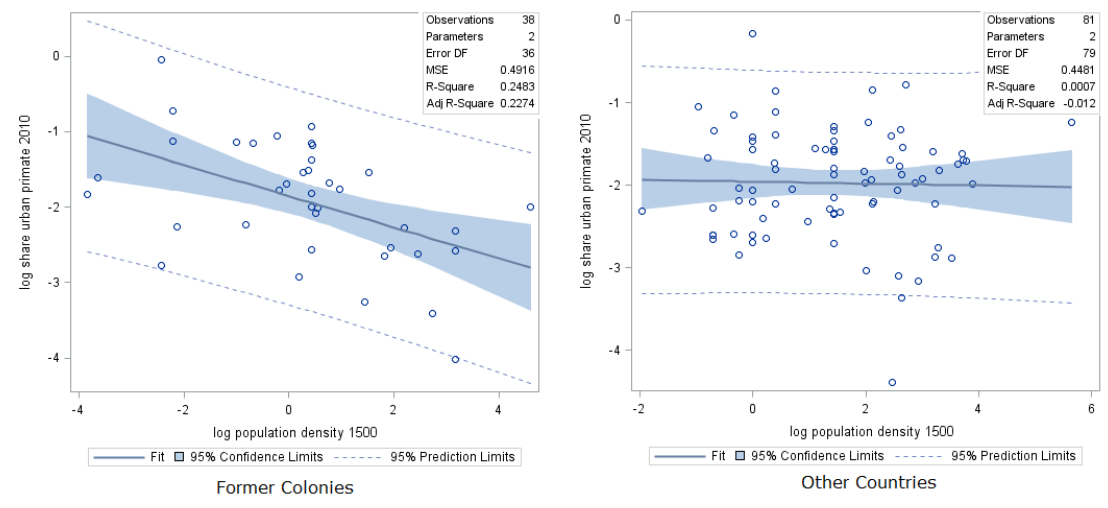

Figure 1: Urbanization Primacy in 2010 and Density in 1500

The main finding of AJR is that economic growth is determined by political institutions

\footnotetext{
${ }^{5}$ Beyond the spatial structural advantage in organizing demonstrations in area with a dense population (in factories thanks to unions or in districts thanks to neighborhood effects and organizations), urban residents located in the capital city also have an information advantage on public spending due to their education, access to the media or to the focus of media on their city (Majumdar et al. 2004).

${ }^{6}$ A related result has been found by Henderson and Wang (2007) showing that democratization favors small cities.

${ }^{7}$ For instance Acemoglu, Robinson and Verdier (2004) have analyzed kleptocratic governments that succeeded in staying in power for long periods despite weak support from the population by relying on divideand-rule tactics. Do these weak dictatorships also have an urban bias?

${ }^{8}$ The second plot presented in Figure (1) for non European former colonies shows that this reversal is not widespread; indeed for countries not colonized the relationship is not significant and the historical spatial economy does not explain the current one.
} 
and by nothing else and in particular not by the geography and culture of nations. Are institutions also the unique determinant of urban primacy? While a vast literature on that subject explains the different size of cities by different kinds of political institutions, Krugman and Livas (1996) proved that agglomeration can emerge without political favoritism: 9 a bad market access can be a sufficient determinant. Trade restrictions that provide an advantage to one city, which becomes the platform for exports and catastrophically attracts all the population.10 By contrast, trade liberalization by providing market access to other cities fosters the dispersion of activities. This conclusion has been disputed a lot; the link between the spatial economy of countries and trade integration is not monotonic, depending on the structure of the economy considered (weak congestion costs, strong share of income spent on industrial goods, etc), a good market access can also foster agglomeration in the largest city (Krugman, 1991; Behrens and Robert-Nicoud, 2014). Buenos Aires, London, Lagos, New-York, Seoul are clear examples where good market access to the world has boosted the size of cities. Faced with this theoretical debate, Ades and Glaeser (1995) found that a one-standard-deviation increase in the share of trade in GDP reduces the size of the main city by about 13 percent. Their analysis using alternative measures of trade integration (import duties and transportation spending) confirms this result; however, these variables are plagued with potential endogeneity bias, and their results using instrumental variables are not significant which leads them to question reverse causality. Nitsch (2006) using geographic characteristics as an instrument for trade, is also skeptical about the role of economic geography on urban concentration 11 In contrast using a difference-in-difference strategy, Karayalcin and Yilmazkuday (2015) show that the Uruguay round of liberalization has reduced the relative size of mega-cities.

Our work differs from that literature on different aspects. First, since the direct measure of trade costs (e.g. tariffs used by Ades and Glaeser, 1995) only represents a part of trade frictions, we use an indirect measure of economics integration based on trade flows. Regressing bilateral trade flows on distance between partner: ${ }^{12}$ and aggregating these results using

\footnotetext{
${ }^{9}$ Candau (2008) extends this model to consider how bad governance affects location choices.

${ }^{10}$ See also Helpman (1998) and Candau (2011) concerning the determinants (and conditions) of this massive agglomeration in one city/region. Candau and Dienesch (2015) integrate in this framework heterogeneous workers and show that only high-skilled workers increasingly choose the core region during the process of integration.

${ }^{11}$ Furthermore Davis and Henderson (2003) in their detailed study of urbanization also confess:

"We experimented with a time varying measure, trade openness. This was statistically insignificant in the IV estimation. Even the sign was sensitive to which instruments were included. Thus we did not include the variable in the results presented in the tables"

${ }^{12}$ In contrast with the literature in international economics that use geographical distance weighted by population (or simply geographical distance) in their trade gravity equation, we compute a bilateral distance
} 
economic geography theory, we compute indicators of market access of these countries to the rest of the world. To our knowledge, this methodology first introduced by Redding and Venables (2004) and used in various studies has never been employed to study urbanization. Secondly, since simple indicators of openness (e.g. exports as a percentage of GDP as used by Barrios et al.) introduce endogenous bias, we propose different instruments for market access such as the genetic distance between partners. The main idea of this instrumentation is that the genetic distance is an exogenous indicator of past international migration and of international trade roads that can explain the current trading system. We also use many controls not available until recently, such as the differential between the intensity of night lights in the city and the intensity of lights in other cities obtained from satellite pictures within a country that allows us to capture spatial income differences.

Third, our results differ from the literature. We show that the rise and fall of mega-cities are mainly explained by institutions. The basic explanation follows the AJR thesis applied to urban economics. European colonialism led to the development of inclusive institutions in previously poor areas which has favored agglomeration economies in urban giants. In contrast, introducing extractive institutions in previously prosperous areas have led to the dispersion of the population.

Section 2 presents our baseline empirical strategy, data and the first results. Section 3 presents an IV strategy and our results, Section 5 describes the conclusions of the study.

\section{Hypothesis, data and preliminary results}

\subsection{Empirical Strategies}

The aim of this paper is to study the causal impact of political institutions and international trade on the concentration of people in the biggest cities. However, before to enter into the details of these two determinants, let's first analyze the impact of institutions in general, considering all the formal and informal constraints and rules (the different codes of conduct, customs, laws, governance) that define political institutions and also economics interactions necessary to trade toward long distance) that causes the concentration of a nation's urban population in its first city. The most simple equation allowing to describe key identification issues of this question may be the following: 13

$$
u_{i t}=\alpha I_{i t}+f_{i}+f_{t}+\varepsilon_{i t}
$$

between partners that takes into account internal distance between cities in each countries.

${ }^{13}$ We follow here a presentation proposed by Combes, Duranton and Gobillon (2011). 
where $u_{i t}$ is the population in the biggest metropolis on the total population ${ }^{14}, f_{t}$ are time fixed effects to control for shocks affecting all individuals at the same time, $f_{i}$ are country fixed effects aimed at capturing characteristics of countries and $I_{i t}$ the variable of institutions of the country $i$ at the period $t$.

The main parameter of interest is $\alpha$, the elasticity of agglomeration with respect to institutions. An unbiased OLS estimate for this parameter is obtained under the following assumption:

$$
\operatorname{Cov}\left(I_{i, t}, f_{i}+f_{t}+\varepsilon_{i t}\right)=\operatorname{Cov}\left(I_{i, t}, f_{i}\right)+\operatorname{Cov}\left(I_{i, t}, f_{t}\right)+\operatorname{Cov}\left(I_{i, t}, \varepsilon_{i t}\right)=0
$$

As it is well known when the covariance in the left hand side of this equation differs from zero, any of the three covariances on the right hand side is a source of bias. We discuss these three terms in turn in order to build our empirical strategy.

Concerning the first term, $\operatorname{Cov}\left(I_{i, t}, f_{i}\right)$, there are some reasons to consider that time varying institutions depend on invariant country characteristics. For instance natural resources or the level of development may have an impact on institutions. A related concern is the fact that the degree of urban primacy may influence institutions. Agglomeration economies may be higher in countries with urban giants and incomes generated from spillover and/or pecuniary externalities can influence institutional change. This relationship is even more obvious concerning international trade, higher level of productivity in a particular sector (e.g. in finance) due to a concentration of activities in one place may influence institutions, at least the formal institutions, of a country. To analyze this bias, consider the following reversed causality between institutions and concentration:

$$
I_{i t}=\beta u_{i t}+\eta_{i}
$$

From classic sociological theory to political modernization theory (Weber, 1909; Lerner, 1964; Lipset, 1959), there is a vast literature that defends this kind of relationship considering that the urban structure affects political mobilization and political change (see Anthony (2014) for a survey).

Using (1) without time effects to simplify, yields:

$$
I_{i t}=\frac{\beta f_{i}+\eta_{i}}{1-\beta \alpha}
$$

\footnotetext{
${ }^{14}$ This share has the advantage to better take into account the size and change of the biggest cities in countries with rural economies (where the central city is not fueled solely by the flow of urban to urban migration but also by the rural one) than classical measures such as the size of the biggest city on the urban population which is moreover dependent on administrative definition of the urban population.
} 
which allow to rewrite the previous covariance as follows:

$$
(1-\beta \alpha) \operatorname{Cov}\left(I_{i, t}, f_{i}\right)=\beta \operatorname{Var}\left(f_{i}\right)+\operatorname{Cov}\left(\eta_{i}, f_{i}\right)
$$

Hence the first origin of the bias comes from the variance of individual specific characteristics $\operatorname{Var}\left(f_{i}\right)$ magnified by the elasticity of institutions with respect to the concentration of people $\beta$. The second channel of an upward bias is the correlation between individual characteristics that explain institutions and urban primacy, one can think respectively to culture and productivity, which lead to conclude that such a bias is likely. ${ }^{15}$

The other origins of bias in (2) is simple to understand, the covariance between institutions and temporal chocks (e.g. a global financial crisis), $\operatorname{Cov}\left(I_{i, t}, f_{t}\right)$ may differs from zero. Finally a covariance between institutions and the error term is the usual definition of endogeneity.

To reduce each of these problems, we first look for a lagged measure of institutions or more precisely a measure of past institutional factors that explain the sustainability of urban agglomeration before the industrial revolution. We choose the density in 1500 to approximate political institutions around that period ${ }^{16}$ Density in 1500 is a good proxy of the current institutions according to AJR, who show that countries that were relatively rich in 1500 (density is considered as a proxy of economic prosperity) have fostered predatory behaviors and extractive institutions by colonizers. We denote this variable $I_{i, 1500}$. We also use a proxy for the current state of political institutions by using the binary view of Acemoglu, Naidu, Restrepo and Robinson (2017) who classify a country as democratic when different databases of political institutions (Freedom House, Polity IV) conclude as such, and dictatorial in the reverse case. This variable is denoted $I_{i t}$.

To take into account institutions that plays a major role in explaining international trade, we regress bilateral trade flows on distance, GDPs and fixed effects and we use the estimates of fixed effects (which typically capture unobservable institutions that explain trade) and distance to build a indicator of market access (also called market potential), here after denoted $\Omega_{i t}$. To reduce the bias of omitted variable, several variables of control are also introduced among which a proxy of the income gap between the biggest city and the rest of the country. While it seems trivial to say that people move from one place to another according to income difference, this variable has never been used to analyze urban primacy until now mainly due to the lack of data at the regional level in developing countries. To approximate this spatial income gap in each country we use the differential between the

\footnotetext{
${ }^{15}$ See for instance Mokyr (2016) who describe how "cultural entrepreneurs", such as Newton, Bacon and many others in England and France, have influenced innovations and growth after 1600.

${ }^{16}$ Available on request, we also use urbanization in 1500 which gives the same result.
} 
intensity of night lights in the biggest city and the intensity of lights in the rest of the country from satellite pictures ${ }^{17}$ We also add classical controls (mainly climate data) for characteristics that are specific to country and time. All these controls are represented in the following equations by a vector $C$.

We start our analysis with a simple cross-sectional analysis (for the year 2010) running ordinary least squares on the following equation:

$$
u_{i}=\alpha I_{i, t-x}+\delta \Omega_{i}+\gamma C_{i}+\varepsilon_{i}
$$

where $I_{i, t-x}$ represent past institutions when the indicator of density in 1500 is used $(t-x=$ $1500)$ or the current level when we use binary variable of democracy $(t-x=0)$. Many papers on the impact of institutions on urban primacy are based on this type of crosssectional analysis. This naive regression presents all the aforementioned bias (and many other), the problem of endogeneity due omitting variables is particularly serious. However, the advantage of this estimation is that it allows to include the invariant historical measure of institutions, $I_{i, 1500}$. This variable which is also a measure of the urban primacy in 1500 , helps to understand the evolution of the spatial economy of nations over a long period of time. The coefficient $\alpha$, if negative, indicates a dispersion of the population from the biggest city, i.e. a reversal in the attractiveness of the biggest city.

We then rely on the panel structure of the data to tackle endogeneity issues (due to omitting variables) by estimating:

$$
u_{i t}=\alpha I_{i, t-x}+\delta \Omega_{i t}+\gamma C_{i t}+f_{i}+f_{t}+\varepsilon_{i t}
$$

This equation is analyzed through the lens of the Fixed-Effect (FE) estimator over the period 1992-2010. This fixed effects estimator is useful to reduce the endogeneity bias of omitted variables. However, the FE procedure is useless to obtain consistent estimates of the timeinvariant proxy of institution, $I_{i, 1500}$, since there is a perfect colinearity between fixed effects and institutions in 1500. As a result, the FE model constraint us to use exclusively time varying institutions, $I_{i t}$, which potentially introduce endogeneity from reversed causality.

To carry out inference on historical density, we thus use the Fixed Effects Filtered (FEF) estimator of Pesaran and Zhou (2016). This estimation is in two steps, first a FE estimation is used to obtain coefficients of the time-varying variables and these estimates are used to filter out the time-varying effects. Then, the residuals from the first step are averaged over

\footnotetext{
${ }^{17}$ Henderson, Storeygard and Weil (2012) have shown that data from outer space are a good proxy of income.
} 
time and computed as a dependent variable in a cross-section OLS estimation that includes historical density and trade network.

To obtain unbiased estimate of the elasticity of agglomeration with respect to the current institutions due to reverse causality, we propose two different Instrumental Variables (IV) estimations.

\subsection{Data}

\section{Cities}

Urban concentration over the period 1962-2010 is calculated by dividing the population in the biggest city by the total population using data from the United Nations, World Urbanization Prospects. Data on density in $1500, u_{i, 1500}$, comes from the Clio-infra database on urban settlement sizes 18 . Data on urbanization in 1500 comes from AJR.

To approximate the spatial urban-income gap, $\Delta_{i t}$, we use the differential between the intensity of night lights in the biggest city and the intensity of lights in other cities obtained from satellite pictures within a country. More precisely, we draw the spatial income gap between the biggest city and the remaining area of every country by using geomatics' tools on Night Lights Data provided by the National Oceanic and Atmospheric Administration's (NOAA) from 1992 to 2010. NOAA processes the raw data collected by the United States Air Force Defense Meteorological Satellite Program (DMSP). The approach used here aims to compute for each country the mean of night lights intensity per square kilometer within areas where the largest city is located. For this purpose, we use Global Administrative Areas (GADM) shapefiles which provide an informative set of countries' administrative boundaries at national and sub-national level. We then cross them with the Natural Earth populated places database which allows to keep the most populated town location in every country. Night Lights rasters provided by NOAA contain pixels to which are attributed digital numbers ranging from 0 to 63 , reflecting the brightness of the light. We used an average value for each pixel for year in which two satellites collected the data. We compute, by country and year, the sum of pixels' values of the biggest city and the sum of pixels for the rest of the country (to approximate light intensity outside the mega-city), we divide these numbers by the geographical surface. The income gap is approximated by the difference between these two values. A lag of ten year is used to avoid reverse causality. ${ }^{19}$ These data limit the period analyzed to 1992-2010.

\footnotetext{
${ }^{18}$ http://www.cgeh.nl/urbanisation-hub-clio-infra-database-urban-settlement-sizes-1500-2000

${ }^{19}$ Robustness tests with different lags are available at https://elearn.univpau.fr/course/view.php?id=12269
} 


\section{Trade}

The indicator of market market access is directly built from the economic geography theory, we modify the market access of Redding and Venables (2004) to take into account the specificity of our research. The first step is to estimate the following trade gravity equation on bilateral exports, coming from COMTRADE, with individual fixed effects $\left(f_{i}^{x}, f_{j}^{m}\right)$ and distance using a pseudo-maximum likelihood (PPML) estimator ${ }^{20}$,

$$
X_{i j}=-\varepsilon \ln \tau_{i j}+a_{i} f_{i}^{x}+a_{j} f_{j}^{m}+\nu_{i j}
$$

where bilateral trade costs $\tau_{i j}$ take the following common specification

$$
\tau_{i j}=d_{i s t_{i j}} \exp \left(\delta_{1} b_{i j}+\delta_{2} c_{i j}+\delta_{3} l_{i j}\right)
$$

with $b_{i j}, c_{i j}, l_{i j}$ are dummies characterizing bilateral trade barriers, respectively a border, past colony links and a common language, dist ${ }_{i j}$ is a weighted measure of distance between cities. The literature usually uses two kind of distance, the simple distances between capitals and a distances between capitals weighted by the population of each countries. Since simple distances between capitals poorly represent the geography of trade costs (in particular for large countries) and introduce bias in the estimation (e.g. over-estimation of the border effect), many articles routinely use the weighted measure proposed by Head and Mayer (2002) and freely available from the GeoDist database of the CEPII. This distance between country $i$ and $j$ is calculated as follows:

$$
\operatorname{dist}_{i j}=\sum_{k}\left(\text { pop }_{k} / \text { pop }_{i}\right) \sum_{l}\left(\text { pop }_{l} / \text { pop }_{j}\right) d_{k l}
$$

where $\operatorname{pop}_{k}$ and $\operatorname{pop}_{l}$ are the population of the largest cities $k$ and $l$. In brief, distance are weighted by the share of the biggest city in the total population which is also our dependent variable. Thus it seems obvious that we cannot use such a measure to explain the concentration of the population in the nation's largest city without introducing endogeneity bias. We thus deviate from the literature by building our own measure using a weighting scheme based on internal distance between the capital and its cities:

$$
\operatorname{dist}_{i j}=\frac{d_{i j}}{d_{i} d_{j}} \text { with }_{i}=\sum_{k} d_{i s t_{i k}}, d_{j}=\sum_{l} d i s t_{j l}
$$

\footnotetext{
${ }^{20}$ Following the work of Silva and Tenreyro (2006), the use of pseudo-maximum likelihood estimators (Poisson and derived econometric models) is justified for treating heteroskedasticity and dealing with the presence of zero trade values.
} 
where $d_{i j}$ is the distance in $\mathrm{km}$ between the biggest cities $i$ and $j$ of each partners, and $d_{i}$ is the internal distance i.e. the sum of all distance between the biggest city $i$ and all other cities $k$ belonging to the same country.

Lastly an important part of the gravity equation making the link between theory and empiric are fixed effects $f_{i}^{x}$ and $f_{j}^{m}$ (and their symmetric expressions) that allow to obtain the predicted value of supply and market capacity.21 Using these predicted values, with our weighted measure of bilateral distance, and estimates of the trade elasticity $\varepsilon$ give the market access:

$$
\Omega_{i}=\left(\exp \left(f_{i}^{m}\right)\right)^{\widehat{a_{i}}}+\sum_{j \neq i}\left[\left(\exp \left(f_{j}^{m}\right)\right)^{\widehat{a_{j}}} d i s t_{i j}^{-\widehat{\varepsilon}} b_{i j}^{\widehat{\delta_{1}}} c_{i j}^{\widehat{\delta_{2}}} l_{i j}^{\widehat{\delta_{3}}}\right]
$$

The gravity equation is estimated in cross-sections to obtain a market access that varies over time, $\Omega_{i t}$.

To get ride of multicolinearity problems in estimating (7) and also of the fact that the market potential can be endogenous to the size of mega-cities, we also use an historical measure of the market access not linked to trade flow but to trade relationship: we calculate an indicator of networks, the so-called out-degree of trade, measuring the number of arcs pointing to partners on the total number of nodes in the bilateral trade network of countries in 1900.22

\section{Institutions}

Concerning institutions, one of the most recent dichotomous measure of democracy proposed by Acemoglu, Naidu, Restrepo and Robinson (2017), hereafter ANRR is chosen. This index, running from 1960 to 2010, combines information from several sources including Freedom House and Polity IV databases. ANRR classify a country as democratic when several databases conclude as such. We also use the instrument of ANRR, who exploit regional waves of democratization and transitions to non democracy as a source of exogenous variation in democracy. More precisely ANRR divide the world in seven regions, $R_{i}$ ( where $i$ is a country in Africa, East Asia and the Pacific, Eastern Europe and Central Asia, Western Europe and other developed countries, Latin America and the Caribbean, the Middle East and the North of Africa, and South Asia) and consider a dummy $D_{i t_{0}}$ taking 1 when the country $\mathrm{i}$ is a democracy at the start of the period. Finally democracy in country i is in-

\footnotetext{
${ }^{21}$ Individual fixed effects also captures internal trade costs that are specific to each countries. Thus at the difference of Redding and Venables (2004) we decide to not include a measure of internal distance beside these fixed effects to avoid double counting (Redding and Venables (2004) makes the critical assumption that every country is a circle which lead them to consider the following formula for internal distance: $\tau^{-\varepsilon}=d i s t^{-\widehat{\varepsilon} / 2}$ with dist $=0.66\left(\frac{\text { area }}{\pi}\right)$ where area is the surface of the country in $\left.\mathrm{km}^{2}\right)$.

${ }^{22}$ See the online appendix which describes in details how this indicator has been built.
} 
fluenced by democracy in the set of countries $J_{i}=\left\{i^{\prime}: i^{\prime} \neq i, R_{i^{\prime}}=R_{i}, D_{i^{\prime} t_{0}}=D_{i t_{0}}\right\}$ which gives the following instrument of political governance:

$$
G_{i t}=\frac{1}{\left|J_{i}\right|} \sum_{i^{\prime} \in J_{i}} G_{i^{\prime} t}
$$

In the words of ANRR, $G_{i t}$ is the jack-knifed average of democracy in a region $\times$ initial regime cell, i.e. a distance-weighted average of democracy among "neighbors". In order to avoid confusion, it is noteworthy that the "geographical components" of this instrument are radically different from the ones included in the market access, the geographical distance is not taken into account and the neighborhood has a wide definition (e.g. every countries in Africa).

For robustness checks regarding the variable of democracy, we also use the polity2 variable, from the PolityIV project and the Freedom House indices of political rights (PR) and civil liberty (CL).

The mortality rates of soldiers, laborers, and bishops during colonial times, used to instrument institutions, come from Albouy (2012).

\section{Other}

Climate data, such as annual precipitation and temperature comes from the CERDI's database. Genetic distance data are used to instrument the market access. These data, based on parts of the DNA that varies through random mutation and drift, comes from Spolaore and Wacziarg (2018) who use information on human micro-satellite variation (Pemberton et al., 2013) at the population (not country) level which are then match to countries using ethnic composition data. More precisely, we use the ancestral genetic distance of Spolaore and Wacziarg (2018) who match to populations as they were in 1500 AD.

\section{$2.3 \quad$ First results}

Table (1), Column (1) and Column (2) examines the cross-sectional patterns running ordinary least squares specification as described in Equation (6) to illustrate the raw data patterns by regressing the log share of urban primacy in 2010 on two different indicators of democracy. In Column 1, based on AJR, this indicator is the log of density in 1500. The bias of reversed causality is reduced by using this historical variable, but this advantage comes at a cost: the effects of the current political institutions cannot be analyzed. In Column 2, we use the indicator of democracy of ANRR. These two columns make our results comparable with the literature on urban primacy that often use cross-sectional data, but as discussed 
at length in Section 1, this specification may provide biased estimates of the variables of interest. Then, in Column (3), (4), (5) and (6), we exploit the panel structure of the data to tackle endogeneity issues by estimating Equation (7) using the Fixed Effects (FE) and the Fixed Effects Filtered (FEF) models.

In Column 1, the elasticity of urban primacy to past density is significant, high and negative, revealing a reversion in the size of the urban concentration relatively to its total population. On average a country that was twice more densely populated in 1500 is now a country where the share of its biggest city in the total population is $23 \%$ smaller than in other countries. We argue that the level of density in 1500 being a proxy of bad governance in the following centuries (countries densely populated in 1500 were richer, which was an incentive to set extractive institution ${ }^{23}$ represents a repulsive force for the native population. This mechanism is consistent with the finding of Nunn and Puga (2012) that rugged terrains were chosen in Africa because these places afforded protection to those being raided during the slave trade. The other side of this result is that countries with a weak concentration of the population in the nation's largest city in 1500 have benefited of inclusive institutions, such as the development of institutions of private property, that made the growth of urban giants profitable by developing agglomeration economies. As in the cross-section analysis, the impact of past density is still negative and significant (Column, 4-5) using the Fixed Effects Filtered (FEF) estimator of Pesaran and Zhou (2017). Finally in Column 2, 3 and 6 , the indicator of democracy is always significant and influences positively the population growth in the biggest city. All these results go against the finding of Ades and Glaeser (1995) who find that bad governance fosters urban concentration at the top of the urban hierarchy. In Column (1), the past network of trade is also significant and negative. This negative impact of the past network of international trade may be related to the particular specialization of some countries, the first globalization has favored land tenets in Latin America for instance (Findlay and O'Rourke, 2009) and thus urbanization was possibly not profitable for this elite. As a result this group may have put in place policies against cities and in particular against large cities that were a fertile land for industrialization. The introduction of fixed effects (Column 5) confirms this result, since the coefficient of the past network, albeit smaller, is still significant. However the introduction of an indicator of the current democracy raises some doubt about the validity of this variable of past network which is no longer significant (Column 6) and thus no longer used in the rest of the paper. Indeed this indicator of past network, reflect more past political institutions and networks between

\footnotetext{
${ }^{23}$ Incentive to set extractive institutions may have also been magnified by the fact that high density countries were also countries were it was harder to settle for colonizers in reason of opposition and/or in reason of disease, as a result the colonial rulers may have concentrated their capital in one unique location, a port for instance, in order to extract rent at the minimal cost.
} 
kings than between traders.

Columns 3 and 4 present the positive impact of the market access. This result supports the thesis that a decrease in trade costs, at least in the first step of development, exacerbates regional disparities (Krugman, 1991). Activities and people tend to concentrate where there is a large market and the market is large where activities are concentrated; trade openness fosters this circular causality of agglomeration in the biggest city.

Regarding controls, the income gap approximated by the difference in night lights between the biggest cities and other cities has the expected positive impact.

The negative impact of temperature in the cross-section analysis (Columns 1-2) may be driven in some countries by the indirect effect of new technologies such as air-conditioning or large investment infrastructures (e.g. dam) that have improved conditions of life in many cities that were initially inhospitable. Once individual fixed effects are introduced, capturing the heterogeneity of countries on these aspects, temperatures are no longer significant (Columns 3-6). 
Table 1: Urban Reversal

\begin{tabular}{l|cccccc}
\hline & OLS & OLS & FE & FEF & FEF & FEF \\
\hline Past Institution & -0.234 & & & -0.226 & -0.252 & \\
(Density in 1500) & $(0.060)^{a}$ & & & $(0.007)^{a}$ & $(0.007)^{a}$ & \\
Democracy & & 0.705 & 0.036 & & & 0.076 \\
& & $(0.319)^{b}$ & $(0.025)^{b}$ & & & $(0.028)^{a}$ \\
Past Trade Network & -0.616 & -0.613 & & & -0.418 & -0.208 \\
(Outdegree in 1900) & $(0.134)^{a}$ & $(0.236)^{b}$ & & & $(0.110)^{a}$ & $(0.185)$ \\
Market Access & & & 0.067 & 0.026 & & \\
& & & $(0.028)^{b}$ & $(0.010)^{b}$ & & \\
Income & -0.003 & -0.019 & 0.065 & 0.062 & 0.058 & 0.094 \\
(Night Lights Data) & $(0.051)$ & $(0.082)$ & $(0.001)^{a}$ & $(0.028)^{b}$ & $(0.029)^{a}$ & $(0.031)^{a}$ \\
Landlock & 0.057 & 0.044 & & 0.223 & 0.206 & 0.567 \\
& 0.310 & 0.446 & & 0.186 & 0.123 & $(0.146)^{a}$ \\
Temperature & -0.818 & -1.132 & 0.026 & 0.002 & -0.055 & -0.055 \\
& $(0.380)^{a}$ & $(0.449)^{a}$ & $(0.821)$ & $(0.134)$ & $(0.135)$ & $(0.135)$ \\
Humidity & -0.175 & -0.182 & -0.006 & -0.005 & -0.001 & -0.001 \\
& $(0.128)$ & $(0.118)$ & $(0.593)$ & $(0.011)$ & $(0.011)$ & $(0.011)$ \\
Constant & 0.216 & 0.662 & -2.441 & & & \\
& $(1.223)$ & $(1.174)$ & $(0.374)$ & & & \\
\hline R-square & 0.549 & 0.447 & 0.999 & & & \\
Observations & 30 & 30 & 315 & 322 & 277 & 270 \\
\hline
\end{tabular}

Note: OLS estimator in Column 1-2, Fixed effects (FE) in Column 3, Fixed Effects Filtered (FEF) in Column 4-6. All variables are in Log. a: significant at $1 \%$, b: at $5 \%$. Data on urban primacy are from the World Development Indicators. Data on density in 1500 from the Clio-infra database on urban settlement sizes, data on urbanization in 1500 from Acemoglu Johnson and Robinson (2002). The binary variable of democracy comes from Acemoglu, Naidu, Restrepo and Robinson (2017). The income gap between the biggest city and other cities is approximated by the differential between the intensity of night lights in the biggest city and the intensity of lights in other cities obtained from satellite pictures. The market access is computed from the estimation of a gravity equation using bilateral exportation from COMTRADE, distance and geographical variables from the CEPII. Fixed Effect estimations include a full set of year and country fixed effects.

\section{IV Strategy}

The main drawback of the previous analysis concerns the reverse causality of trade and political institutions, indeed, as discussed in Section 2, political institutions may be influenced by the spatial economy, and furthermore international trade is often dependent of the performance of the biggest city. To take into account these links, we propose a two-stage least squares (2SLS) estimation strategy, with a "zero-stage" to find suitable instruments for these institutions in the first stage. This 2SLS identification strategy with a zero-stage is inspired by Docquier et al. (2016). 


\subsection{Two steps SLS identification strategy with a zero-stage}

The zero-stage is based on the finding that the mortality rate faced by settlers is a good instrument of the current institution (AJR). Since this proposition has stirred up questions (Albouy, 2012) 24 , we also take a more contemporaneous variable by using the regional waves of democratization and transitions to non democracy as an instrument (this is the instrument used by ANRR, already described in the previous section).

Denoting $H_{i}$ the historical mortality rates of soldiers, laborers, and bishops during colonial times (source: Albouy, 2012), $I_{i}$ the indicator of democracy (source: ANRR), and $G_{i}$ the measure of political governance based on waves of democratization (defined by Equation 10), we estimate the following equation:

$$
I_{i}=\beta H_{i}+\gamma G_{i}+\vartheta_{i}
$$

This equation is simply an extension of AJR using a different dependent variable (democracy instead of expropriation risks), and an additional variable $G_{i}$. Finally while AJR estimates this equation for one year only, we regress it on each year of our sample which gives an historical-geographical instrument, denoted $\widehat{H_{i t}^{g}}$ that varies over time. ${ }^{25}$ Democracy effect identification will come from this time-varying predicted instrument $\widehat{H}_{i t}^{g}$ that captures the discretionary variations in institutions. It reflects the exogenous component of democracy variable as a consequence of distant past shocks in the contemporaneous institutions trend. Concerning the endogeneity of trade, we follow the same strategy by using the ancestral genetic distance (Spolaore and Wacziard, 2018). The relevance condition asserting that this variable is a good instrument to predict the endogenous dependent variable, i.e. trade, is well established. For instance, Guiso, Sapienza and Zingales (2009) find that genetic distance is a good proxy for cultural proximity, which impacts on the trust between two partners and then on trade exchanges. Spolaore and Wacziard (2018) present clear evidences that genetic distance acts as a temporary barrier to the diffusion of innovations and development. Giuliano, Spilimbergo and Tonon (2014) find that genetic distance is a good proxy for transportation costs between countries in reason of international migrations. The variation in genetic distance are partially explained by international migrations which partially cause international trade via business and social networks. See for instance Rauch and Trindade (2002) on the impact of the ethnic networks on trade. The market access is then regressed on ancestral genetic distance, denoted $D_{i}^{g}$, for each year of our sample, which enables to get

\footnotetext{
${ }^{24}$ See however the response of AJR (2012).

${ }^{25}$ In other terms, from the estimation of 11 we compute a different $\widehat{H_{i}^{g}} \equiv \widehat{\beta} H_{i}+\widehat{\gamma} G_{i}$ for each year between 1962 and 2010.
} 
an instrument of the market access based on genetic distance that varies over time, hereafter denoted $\widehat{D_{i t}^{g}}$.

The first step explains the variation of institutions by using the exogenous variable of institutions defined in the previous step:

$$
I_{i t}=\varsigma \widehat{H_{i t}^{g}}+f_{i}+f_{t}+C_{i t}+\chi_{i t}
$$

and in a similar way the variation over time of the market access: ${ }^{26}$

$$
\Omega_{i t}=\varrho \widehat{D_{i t}^{g}}+f_{i}+f_{t}+C_{i t}+v_{i t}
$$

The interest of this first step is that $\varsigma$ is estimated from within changes in $\widehat{H_{i t}^{g}}$ which, by depending on the distance-weighted average of democracy among neighbors, is an exogenous variable of the current urban primacy. In a similar way $\varrho$ is not estimated by cross-country difference but by within changes of a genetic distance between partners which is certainly not a function of trade. Individual fixed effects in the two equations are particularly important to control for differences in the level of development. The term $C_{i t}$ represents three variables of control that are used in the two stages: the precipitation, the temperature and the gap in the intensity of night lights.

Finally the second step uses the predicted values of the "historical-geographical" institutions and of the predicted value of "genetic" market access as follows:

$$
u_{i t}=\widehat{\varsigma} \widehat{H_{i t}^{g}}+\widehat{\varrho} \widehat{D_{i t}^{g}}+f_{i}+f_{t}+C_{i t}+\epsilon_{i t}
$$

\subsection{Results of the Zero-Stage}

Table (2) confirms the positive impact of waves of democratization on institutions. Results are less clear concerning the effect of the mortality rate of colonizers. Coefficients associated to the colonizers mortality rate are significant only between 1962 and 1972 which may suggest an erosion of the bad influence of past colonial institutions. However, additional estimations provided in the online appendix shows that the initial result of ARJ is verified over the whole period when we use a different indicator of democracy, i.e. the mortality rate of colonizers explains institutions as measured by the polity 2 index of democracy, the Freedom House

\footnotetext{
${ }^{26}$ As a robustness check, we have used different instruments for the market access in this first stage. Instead of using genetic distance, in the online appendix we present an instrumentation based on the mortality rate of settlers (since the market access may be a function of past institutions which may biased our results in the second stage) and we find similar result.
} 
indices of political rights (PR) and civil liberty (CL). It is also noteworthy that this indicator of mortality has a small impact on institution in comparison with waves of democratization. ${ }^{27}$

Table 2: Democracy (ANRR index), zero stage

\begin{tabular}{c|c|c|c|c|c|c|c}
\hline & 1962 & 1965 & 1972 & 1982 & 1992 & 2002 & 2010 \\
\hline Waves of democratization & 0.957 & 0.961 & 0.696 & 0.810 & 0.894 & 0.929 & 0.979 \\
$G_{i}$ & $(0.076)^{a}$ & $(0.076)^{a}$ & $(0.216)^{a}$ & $(0.161)^{a}$ & $(0.153)^{a}$ & $(0.198)^{a}$ & $(0.149)^{a}$ \\
Mortality rate of colonizers & -0.030 & -0.042 & -0.165 & -0.063 & -0.076 & 0.028 & 0.010 \\
$H_{i}$ & $(0.017)^{c}$ & $(0.017)^{b}$ & $(0.096)^{c}$ & $(0.080)$ & $(0.087)$ & $(0.066)$ & $(0.067)$ \\
Constant & 0.147 & 0.206 & 0.783 & 0.338 & 0.383 & -0.038 & -0.016 \\
& $(0.127)$ & $(0.123)$ & $(0.470)$ & $(0.362)$ & $(0.425)$ & $(0.328)$ & $(0.296)$ \\
\hline R-squared & 0.773 & 0.776 & 0.515 & 0.356 & 0.427 & 0.558 & 0.538 \\
Observations & 35 & 35 & 36 & 36 & 36 & 36 & 36 \\
\hline
\end{tabular}

Note: OLS estimator. Mortality rate variables is in Log. a: significant at 1\%, b: at $5 \%$. The mortality rate of colonizers (in $\log$ ) comes from Albouy (2012). Data on democracy are from Acemoglu, Naidu, Restrepo, Robinson (2017), denoted ANRR in the title of this table, and instrumented with their instrument based on waves of democratization.

In Table (3) we present some of the zero-stage of the market access. Throughout the period we find a negative impact of the genetic distance on the market access.

Table 3: Market Access, zero stage

\begin{tabular}{l|l|l|l|l|l|l} 
& 1962 & 1972 & 1982 & 1992 & 2002 & 2010 \\
\hline Genetic Distance & -0.421 & -0.360 & -0.550 & -0.393 & -0.345 & -0.364 \\
& $(0.108)^{a}$ & $(0.159)^{b}$ & $(0.187)^{b}$ & $(0.192)^{b}$ & $(0.188)^{b}$ & $(0.105)^{b}$ \\
Constant & 0.820 & -0.115 & 0.328 & 0.813 & 1.602 & 1.422 \\
& $(0.321)^{b}$ & $(0.481)$ & $(0.565)$ & $(0.587)$ & $(0.585)^{a}$ & $(0.313)^{a}$ \\
\hline R-square & 0.185 & 0.066 & 0.095 & 0.047 & 0.037 & 0.151 \\
Observations & 37 & 38 & 38 & 38 & 38 & 37 \\
\hline
\end{tabular}

Note: OLS estimator. All variables are in Log. a: significant at 1\%, b: at 5\%. Data on genetic distance in 1500 are from Spolaore and Wacziarg (2018). The market access is computed from the estimation of a gravity equation using bilateral exportation from COMTRADE, distance and geographical variables from the CEPII.

\subsection{Results of the first stage}

Table (4. Column 1) presents the first stage described by Equation (12). As expected our historical and geographical instrument based on mortality rates and on waves of globalization significantly explains the level of democracy. This first stage confirms the different results obtained by AJR and ANRR. The coefficients on the instrument variables are highly significant. We present the F-test statistics that reject the joint null effect hypothesis of these IVs

\footnotetext{
${ }^{27}$ Not reported here we also compute our instrument by using only the predicted value of the indicator of governance based on the waves of democratization (i.e. by excluding the mortality rate such as $\widehat{H_{i}^{g}} \equiv \widehat{\gamma} G_{i}$ ) and we find similar results in the following stages. The small estimates of $H_{i}$ (see Table 2 may explains why our results hold with and without this variable.
} 
and they are above 10, the threshold proposed by Staiger and Sotck (1997). As a robustness check we also run an estimation by excluding the mortality rate in the zero-stage, and thus by using an instrument in this first step only based on the waves of democratization. We do not report this estimation since results are almost identical (we find a coefficient of 0.871 with a RSE of 0.052).

Column (3) presents the first stage regressing the market access on its instrument with various controls (see Equation, 13). As required, the instrument of trade openness based on genetic distance significantly explains the market access. This result confirms, in a different way, the main finding of Giuliano, Spilimbergo and Tonon (2014) that genetic distance captures transportation costs between countries.

Column (2) and (4) propose a simple test to verify that there is no other problems of endogeneity in this strategy by analyzing whether the market access explains the current level of democracy. Indeed the causal link of globalization on democracy has be discussed a lot by economists and political scientists (e.g. Milner and Mukherjee, 2009) and not directly addressed in this paper until now. Our result confirms the finding of this literature that trade openness does not explain the process of democratization (when adequate IV are used).

Column (3) shows that the instrument of the market access has no impact on institutions, while Column (4) shows that the instrument of institutions does not impact on the market access.

Table 4: Democracy and Trade, First stage

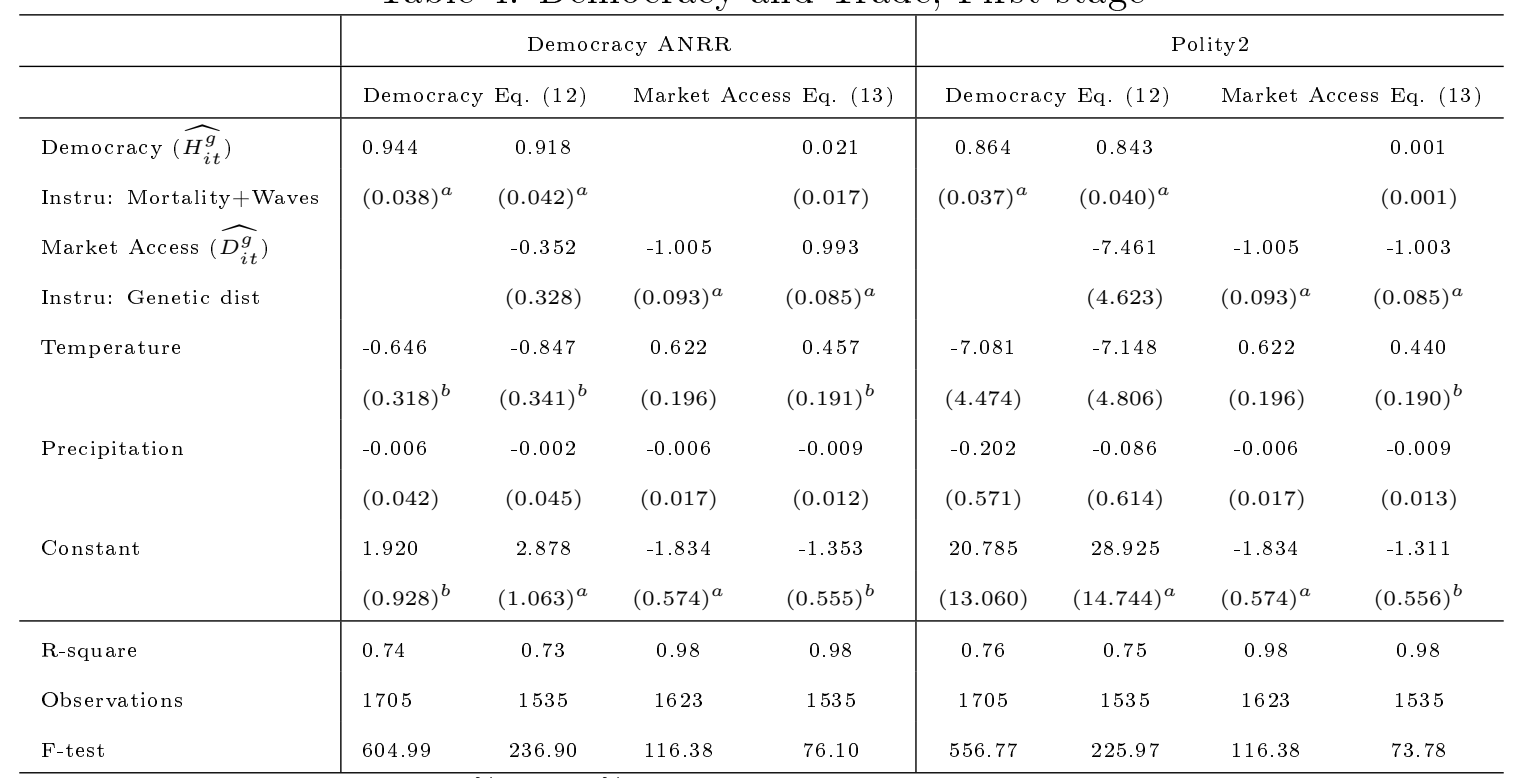

Note: 2 SLS procedure, a: significant at $1 \%$, b: at $5 \%$. The market access is computed from the estimation of a gravity equation using bilateral exportation from COMTRADE, distance and geographical variables from the CEPII. This market access is instrumented using genetic distance in 1500 from Spolaore and Wacziarg (2018). Data on democracy are from Acemoglu, Naidu, Restrepo, Robinson (2017) and instrumented with their instrument, denoted ANRR, based on waves of democratization and with the mortality rate of colonizers provided by Albouy (2012). All estimations include time effects and individual fixed effects. 
Column (5), (6), (7) and (8) present exactly the same specification with a different measure of democracy. We use the variable Polity2 instead of the variable of democracy of ANRR. Results are not affected by this change.

\subsection{Results, second stage}

Table (5. Column 1) shows the results obtained by estimating the second stage described by Equation (14). Column 2 presents a "half-naive" estimation, where the democracy is instrumented but the market access is not. Column 3 present the symmetrical estimation, where the market access is instrumented while the democracy is not.

In all estimations reported in Table (5), whatever the specification used, we find that the indicator of democracy, instrumented by past mortality rates and by waves of democratization favors agglomeration in the biggest city ${ }^{28}$ These results indicate that the negative impact of democracy found by Ades and Glaeser (1995) and Henderson and Wang (2007) may be due to a lack of control and/or to endogeneity bias. Another possibility, which is more interesting, is that there is something specific in our sample of countries. Ades and Glaeser (1995) for instance consider a sample of seventy countries without considering the history of these States. Our analysis is slightly different since we focus our research exclusively on countries colonized by Europeans 500 years ago following the arguments of AJR and of many historians that the long run effects of colonization are still unclear. As a result, it is possible that countries not colonized by Europeans have developed institutions that shape differently their economic geographies.

Concerning the second hypothesis, the market access is never significant, which reveals how the previous results done without controls on time-varying institutions and without an exogenous measure of trade openness were misleading. This is in accordance with the skeptical view of Ades and Glaeser (1995) and Henderson and Wang (2007) about the impact of international trade on the urban pattern. The same estimations are done in Column (4), (5) and (6) but with the variable polity2 and based on the first step of Columns (5) and (6) of the previous Table (4). The estimation of (14) in Column (4), which is the most careful estimation correcting for the endogeneity of the market access and of institutions, provides the same result than Column 1.29

\footnotetext{
${ }^{28}$ When we compute the instrument of democracy by only considering waves of democratization, we get a very similar result not reported here but available on request (the coefficient is equal to 0.115 and highly significant with a RSE of 0.036).

${ }^{29}$ On the contrary the naive estimation in Column (5), where the market access is not intrumented, shows that this variable is significant (however only at $10 \%$ ), revealing the interest of the IV strategy concerning the impact of trade integration on urban primacy.
} 
Table 5: Trade, Institutions and Urban Primacy

\begin{tabular}{|c|c|c|c|c|c|c|}
\hline \multirow[t]{2}{*}{ dep: } & \multicolumn{3}{|c|}{ Democracy ANRR } & \multicolumn{3}{|c|}{ Polity 2} \\
\hline & Eq. 14 & \multicolumn{2}{|c|}{ Naive reg } & Eq. 14 & \multicolumn{2}{|c|}{ Naive reg } \\
\hline Market Access $\left(\Omega_{i t}\right)$ & \multicolumn{3}{|c|}{0.048} & & $\begin{array}{c}0.052 \\
(0.031)^{c}\end{array}$ & \\
\hline Market Access $\left(\widehat{\varrho} D_{i t}^{g}\right)$ & -0.158 & & -0.146 & -0.250 & & -0.148 \\
\hline Instru: Genetic & $(0.145)$ & & $(0.173)$ & $(0.154)$ & & $(0.166)$ \\
\hline Democracy $\left(I_{i t}\right)$ & & & $\begin{array}{c}0.038 \\
(0.016)^{a}\end{array}$ & & & $\begin{array}{c}0.007 \\
(0.004)^{c}\end{array}$ \\
\hline Democracy $\left(\widehat{\varsigma H_{i t}^{g}}\right)$ & 0.104 & 0.092 & & 0.009 & 0.006 & \\
\hline Instru: Mortality+Waves & $(0.034)^{a}$ & $(0.034)^{a}$ & & $(0.004)^{b}$ & $(0.004)^{c}$ & \\
\hline \multirow[t]{2}{*}{ Light } & 0.085 & 0.074 & 0.075 & 0.083 & 0.071 & 0.081 \\
\hline & $(0.021)^{a}$ & $(0.021)^{a}$ & $(0.020)^{a}$ & $(0.021)^{a}$ & $(0.021)^{a}$ & $(0.020)^{a}$ \\
\hline \multirow[t]{2}{*}{ Temperature } & 0.218 & 0.051 & 0.171 & 0.225 & 0.022 & 0.159 \\
\hline & $(0.136)$ & $(0.121)$ & $(0.135)$ & $(0.136)^{c}$ & $(0.120)$ & $(0.133)$ \\
\hline \multirow[t]{2}{*}{ Precipitation } & -0.008 & -0.007 & -0.006 & -0.007 & -0.006 & -0.007 \\
\hline & $(0.012)$ & $(0.012)$ & $(0.011)$ & $(0.012)$ & $(0.012)$ & $(0.012)$ \\
\hline \multirow[t]{2}{*}{ Constant } & -1.753 & -1.761 & -1.551 & -1.492 & -1.636 & -1.508 \\
\hline & $(0.373)^{a}$ & $(0.346)^{a}$ & $(0.369)^{a}$ & $(0.352)^{a}$ & $(0.334)^{a}$ & $(0.386)^{a}$ \\
\hline R-square & 0.99 & 0.99 & 0.99 & 0.99 & 0.99 & 0.99 \\
\hline Observations & 306 & 306 & 306 & 306 & 306 & 306 \\
\hline
\end{tabular}

Note: 2SLS procedure, a: significant at 1\%, b: at 5\%., c: at $10 \%$ The market access is computed from the estimation of a gravity equation using bilateral exportation from COMTRADE, distance and geographical variables from the CEPII. This market access is instrumented using genetic distance in 1500 from Spolaore and Wacziarg (2018). Data on democracy are from Acemoglu, Naidu, Restrepo, Robinson (2017) and instrumented with their instrument, denoted ANRR, based on waves of democratization and with the mortality rate of colonizers provided by Albouy (2012). All estimations include time effects and individual fixed effects.

\subsection{Discussions}

The link between urban planning and institutions studied here is binary (dictatorship versus democracy) which makes our paper more easily comparable to the literature. However, political regimes are richer than this simple binary difference and many interesting results are certainly hidden by this presentation. This is well summarized by Duranton (2008) who wrote that "this type of explanation [i.e. Ades and Glaeser (1995)] implicitly assumes fairly strong state institutions able to tax their countryside and redistribute the proceeds to the primate city. On the contrary, it may be argued that undemocratic and unstable regimes are weak and favor primate cities by default." In an online appendix, $\sqrt[30]{6}$ we briefly develop this discussion. We find that in democratic states, the political regime has no role whatever the urban pattern. In contrast, in countries with weak dictatorship and with an urban giant,

\footnotetext{
${ }^{30}$ Due to the length of the paper and in order to respond to the "Basic Requierements" of the journal, this part and some other appendices have been posted on our own webpage (as well as the database and Stata code), available at https://elearn.univ-pau.fr/course/view.php?id=12269
} 
more democracies foster the development of the largest city, maybe by "default" as argued by Duranton (2008).

Another discussion that may be interesting before to conclude, concerns the robustness of our result regarding the econometric used here. The previous results are based on a linear functional relationship and on strong assumptions regarding the IV strategy. The combination of non-random selection into the process of democratization and the omission of non-linear relationships can biased estimates. We thus lead different non parametric estimations (see our online appendix) which confirms the results obtained so far, the urban primacy has been promoted by democratic regimes.

\section{Conclusion}

Institutions and first cause matter, not trade, in explaining the relative fall of the biggest cities in former European colonies. Our analysis documents the negative effects of bad governance on the current level of urbanization. We find that the reversal in urban primacy is due to past institutions related to colonization. Bad governance and extractive institutions inherited from colonization have reduced the population growth of the biggest city in many countries.

Regarding the literature, we have improved the analysis on different aspects by working with panel data (e.g. the analysis of Ades and Glaeser (1995) is in cross-section only), by using new controls (e.g. satellite data lights, market access measures) and new instruments (settlers mortality, waves of democratization) to explain urban primacy. All our different strategies (using OLS, IV, matching techniques) lead to the same conclusion: the democracy of the former European colonies has favored cities at the top of the urban hierarchy. As a result, we do not share the conclusion of Ades and Glaeser (1995) who wrote that what "was true in Rome, 50 B.C.E., is still true in many countries today", on the contrary, we document that dictatorship is no longer a force of agglomeration in the biggest cities of our sample. This result has concrete consequences, it means that in many countries where democratic institutions are improved, we can forecast a more significant growth of the biggest city than what has been predicted until now with major implications for infrastructures, public health, sanitation, productivity and inequality. 


\section{References}

[1] Acemoglu, D., S. Johnson, and J A. Robinson (2002), 'Reversal of Fortune: Geography and Institutions in the Making of the Modern World Income Distribution'. The Quarterly Journal of Economics, 117(4): 1231-1294.

[2] Acemoglu, D., S. Johnson, and J A. Robinson (2012), 'The Colonial Origins of Comparative Development: An Empirical Investigation: Reply'. American Economic Review, 102(6): 3077-311

[3] Acemoglu, D., Naidu, Restrepo and Robinson (2017), 'Democracy Does Cause Growth', forthcoming Journal of Political Economy

[4] Acemoglu, D., Robinson, J. A. and T. Verdier, (2004), 'Kleptocracy and Divide-andRule: A Model of Personal Rule', Journal of the European Economic Association, 2(23):162-192.

[5] Ades, A. and E. Glaeser (1995), 'Trade and Circuses: Explaining Urban Giants', Quarterly Journal of Economics 110: 195-227.

[6] Albouy, D. (2012), 'The Colonial Origins of Comparative Development: An Empirical Investigation: Comment', American Economic Review, 102 (6): 3059-76.

[7] Anthony, R. M., (2014), 'Bringing up the past: Political experience and the distribution of urban populations', Cities, Volume 37, Pages 33-46

[8] Bai, C-H., C-T. Hsieh and Z., Song (2019), 'Special Deals with Chinese Characteristics', forthcoming in NBER Macroeconomics Annual.

[9] Bates, R. H, (1981), Markets and States in Tropical Africa: The political basis of agricultural policies. Berkeley: University of California Press.

[10] Behrens, K. and F. Robert-Nicoud (2014), 'Survival of the Fittest in Cities: Urbanisation and Inequality', The Economic Journal, 124(581): 1371-1400.

[11] Candau, F. (2008), 'Good Governance, Trade and Agglomeration', Papers in Regional Science, 87(4): 483-504.

[12] Candau, F. (2011), 'Is Agglomeration Desirable?', Annals of Economics and Statistics, 101/102: 203- 228 . 
[13] Candau, F. and E. Dienesch (2015), 'Spatial distribution of skills and regional trade integration'. The Annals of Regional Science, 54(2): 451-480.

[14] Collier, P. and A. J. Venables (2013), 'Housing and Urbanization in Africa: unleashing a formal market process', Centre for the Study of African Economies, Working Paper Series 2013-01, University of Oxford.

[15] Combes, PP., G. Duranton and L. Gobillon, 2011. 'The identification of agglomeration economies', Journal of Economic Geography, 11(2): 253-266.

[16] Crenshaw E.M. and R. M Anthony (2014), City Size and Political Contention, International Journal of Sociology, 44(4):7-33.

[17] Davis, J. and J.V. Henderson (2003), 'Evidence on the political economy of the urbanization process', Journal of Urban Economics 53: 98-125.

[18] Docquier, F., E. Lodigiani, H. Rapoport and M. Schiff, Emigration and democracy, Journal of Development Economics 120 (2016) 209-223.

[19] Duranton, G., (2008), 'Viewpoint: From cities to productivity and growth in developing countries', Canadian Journal of Economics, 41(3):689-736

[20] Eeckhout, J. (2004), Gibrat's Law for (All) Cities, American Economic Review, 94(5): 1429-1451.

[21] Feler, L. and J.V. Henderson (2011), 'Exclusionary policies in urban development: Under-servicing migrant households in Brazilian cities', Journal of Urban Economics, $69(3): 253-272$.

[22] Findlay, R. and K.H. O'Rourke (2009), Power and Plenty: Trade, War, and the World Economy in the Second Millennium. Princeton U Press.

[23] Giuliano, P., A. Spilimbergo and G. Tonon (2014), 'Genetic distance, transportation costs, and trade', Journal Economic Geography, 14 (1): 179-198.

[24] Guiso, L., P. Sapienza and L. Zingales (2009), 'Cultural Biases in Economic Exchange?', The Quarterly Journal of Economics, 124 (3): 1095-1131.

[25] Head, K. and T. Mayer (2002), 'Illusory Border Effects: Distance Mismeasurement Inflates Estimates of Home Bias in Trade', CEPII Working Paper 2002-01. 
[26] Helpman, H., (1998), The Size of Region, In D. Pines, E. Sadka, and I. Zildcha (eds.). Topic in public economics. Theorical and Applied Analysis. Cambridge: Cambridge University Press: $33-54$.

[27] Henderson, J. V., A. Storeygard and D. N. Weil. (2012), 'Measuring Economic Growth from Outer Space', American Economic Review, 102(2): 994-1028

[28] Henderson, J. V. and H.G. Wang (2007), 'Urbanization and City Growth: the Role of Institutions', Regional Science and Urban Economics, 37(1): 283-313.

[29] Kaufmann, D., A. Kraay and M. Mastruzzi (2010), The worldwide governance indicators : methodology and analytical issues, Policy Research Working Paper Series 5430, The World Bank.

[30] Karayalcin, C. and H. Yilmazkuday (2015), 'Trade and Cities', World Bank Economic Review, 29(3): 523-549.

[31] Krugman, P., (1991), 'Increasing Returns and Economic Geography', The Journal of Political Economy, 99(3): 483-499

[32] Krugman, P. and E.R. Livas (1996), 'Trade policy and the Third World metropolis', Journal of Development Economics, 49(1): 137-150.

[33] Lerner, D., (1958), The Passing of Traditional Society: Modernizing the Middle East. New York: Free Press.

[34] Lipset, S. M. (1959), 'Some Social Requisites of Democracy: Economic Development and Political Legitimacy', American Political Science Review, 53(1): 69-105.

[35] Lipton, M. (1977), Why Poor People Stay Poor: Urban Bias in World Development, Cambridge, MA: Harvard University Press.

[36] Majumdar, S., A. Mani and S. Mukan (2004), 'Politics, information and the urban bias', Journal of Development Economics, 75(1): 137-165.

[37] Marshall, M G. and K Jaggers (2007), Polity IV Project: Dataset Users' Manual, George Mason University and Center for Systemic Peace.

[38] Mokyr, J., (2016), A Culture of Growth: The Origins of the Modern Economy, Princeton University Press.

[39] Milner V. H. and B. Mukherjee (2009), 'Democratization and Economic Globalization', Annual Review of Political Sciences, 12(1):163-81 
[40] Nitsch, V., (2006), 'Trade Openness and Urban Concentration: New Evidence', Journal of Economic Integration 21(2), 340-362.

[41] Nunn, N. and D Puga (2012), 'Ruggedness: The Blessing of Bad Geography in Africa', Review of Economics and Statistics, 94(1):20-36.

[42] Pemberton, T. J., M. DeGiorgio, and N. A. Rosenberg (2013), 'Population Structure in a Comprehensive Genomic Data Set on Human Microsatellite Variation', G3: Genes, Genomes, Genetics, 3(5): 903-919.

[43] Pesaran, H. and Q. Zhou (2016), Estimation of time-invariant effects in static panel data models, Econometric Reviews, 37(10): 1137-1171.

[44] Rauch, J E. and V. Trindade (2002), 'Ethnic Chinese Networks in International Trade', Review of Economics and Statistics, 84(1): 116-130

[45] Redding, S. and A.J. Venables (2004), 'Economic geography and international inequality', Journal of International Economics 62: 53-82.

[46] Santos Silva, J. and S. Tenreyro (2006), 'The log of gravity', The Review of Economics and Statistics, 88: 641-658.

[47] Spolaore, E., and R. Wacziarg (2018), 'Ancestry and Development: New Evidence', $33(5)$ : 748-762.

[48] Staiger, D. and J. Stock (1997), 'Instrumental Variables Regression and Weak Instruments', Econometrica, 65(3): 557-586.

[49] Weber, M (1909), Urbanization and Social Structure in the Ancient World, in Weber: Selections in Translation, edited by W. G. Runciman, 290-314. Cambridge: Cambridge Univ. Press 